\title{
Human Mobility Towards Turkey: A Retrospective Endeavor to Understand*
}

\author{
Merve Suzan ILIK BİLBEN ** \\ 0000-0003-3668-0848
}

Last decade, Turkey experienced the most extensive migration raids in its history. The transition of Turkey from a migrant-sending country to a transit and target country is one of

Submitted: 02.03. 2021

Revision Requested: 19.05. 2021

Final Revision Received: 22.05. 2021

Accepted: 29. 07. 2021

Published Online: 15.08. 2021

\section{Keywords:}

\section{Sociology}

International Migration

Turkey

Social Cohesion

Securitization the most referenced periodization practices in the literature. However, Anatolia has a history of migration with very different experiences by its location. Human mobility is inherent to the structure of this geography, even though its quality and quantity have changed and transformed in the historical process. Therefore, it is important to understand that Turkey, which is home to the most significant number of forced migrants in the twenty-first century, is historically a country of migration. Hence, in this article that attempts to understand human mobility towards Turkey, we have focused on Turkey's changing position on the international migration scheme after summarizing the migration flows before and during the republic period to capture the holistic perspective. Based on the current research, reports, and statistical data, this article seeks a better understanding of the possibility and sustainability of social cohesion and integration in Turkey, in a global world characterized by uncertainties, risks, and pursuits.

${ }^{* *}$ This article refers to a part of the author's master's thesis titled "A New Global Problem, An Old Coping Mechanism: Anthropogenic Climate Change Induced Migrations and Turkey", completed at Akdeniz University Social Sciences Institute.

"Corresponding Author: M. Suzan Ilık Bilben (Res. Assit.), Akdeniz University, Faculty of Letters, Department of Sociology, Antalya, Turkey. 凶mervesuzanilik@akdeniz.edu.tr

Citing This Article: Ilık-Bilben, M. S. (2021). Human Mobility Towards Turkey: A Retrospective Endeavor to Understand. Sosyolojik Bağlam Dergisi, 2 (2), 55-74. Doi: 10.52108/2757-5942.2.2.4 


\section{Introduction}

In the "Age of Migrations" (Castles \& Miller, 2008), where the world population mobility is increasing and the turmoil in one part of the world can easily affect not only its surroundings but also the other end of the world. The tension between countries and societies is increasing, the "culture of living together" has become more critical than ever. It is possible to assert that the act of migration is generally a change of the place of residence as "permanent" or "semi-permanent", out of the administrative border (Faist, 2003, p. 41). In other words, many theories have been put forward to explain the functioning of the act of migration, which is defined as "moving from the original place to the desired place" (Karpat, 2003, p. 3).

The principal concept on which almost all definitions of migration are based is human 'mobility'. However, this basic approach is not sufficient to explain the multidimensional and multi-layered migration phenomenon. Since the border between migration and mobility is not clear, we can speak of the existence of many types of migration, which complicates distinctions based on time (shortmedium-long, cyclical, reverse) and distance (different circulation patterns and different circulation geographies) scale (Mavroudi \& Nagel, 2016, p. 4). The perception of space is not only a tangible asset for the individual, but also an inseparable part of the sense of identity and belonging, and the most visible component of his cultural existence. For this reason, migration is sometimes the result of a change and sometimes a harbinger of many changes (Göker, 2015, p. 28). Migration, which can take place both as a cause and as a result in every period of history and is one of the influential factors in the demographics, culture, economy, and politics of societies, has been a phenomenon studied by different scientific disciplines due to its sophistication (Gürkan, 200, p. 1). The reason why migration is a sociological phenomenon, among many other disciplines, is the existence of intertwined social transformations and the vast expanse of social problems caused by migration.

The act of spreading and settling on the world itself is a history of migration. Migration has always existed, even though its origins and consequences have significantly changed throughout history. According to Ortayll (2006, p. 19), the necessary action of people as a society is "migration", if migration has ended somewhere, it implies that the society is dissolving. Migration events that affect the development and alteration of human history (Çağlar, 2011, p. 56) are, in a way, one of the creators of history. Almost all of the changes that carve out human history, such as natural disasters, conquests, geographical discoveries, colonization, industrialization, and international trade are somehow the cause or result of migration. The phenomenon of international migration, which is dynamic and multidimensional, is a phenomenon that reshapes societies and cultures all over the world, beyond being a movement that transcends borders. The current populations of countries such as the United States of America, Canada, Australia, New Zealand, and Argentina, known as "classical immigrant countries", are the result of a history of large-scale migrations, often at the expense of the indigenous population (Castles \& Miller, 2008, p. 11). As in the case of Israel, immigration can play a central role in the construction of a country (Öner, 2012, p. 13).

Although international migration movements have existed since the early periods of human history, efforts to establish a regime in this area have started relatively recently. Population movements during and after the Second World War triggered cooperation efforts on international migration and made possible the establishment of the United Nations High Commissioner for Refugees (UNHCR) and the European Intergovernmental Committee on Migration (ICEM), known as the International Organization for Migration (IOM) nowadays (Ihlamur-Öner, 2012, p. 578). Since the 1990s, but especially since 2000, we have seen that international migration studies and global cooperation have increased. While transboundary human movements have shaped states and societies since ancient times, the distinctive features of human movements in recent years are their global scope, centrality in local and international politics, and enormous economic and social consequences (Castles \& Miller, 2008, p. 5). Then, as Kümbetoğlu (2012, p. 51) states, "The impact of migration on human lives, efforts for harmony, integration, and re-establishment of life make migration studies not only for recording purposes but also to be in-depth and detailed studies". Cross- 
border studies, which try to illuminate the link between migration and many different fields such as youth, gender, belonging, identity, health, urban space, citizenship, development, border control, have a significant role in understanding cross-border mobility (see ERC, 2017).

While the migration literature establishes connections between the sub-headings it creates for analytical purposes and the main reasons that lead people to move, on the other hand, it stumbles into "producing a kind of knowledge and perception that these subheadings are separate situations as if they can be completely abstractable from each other" (Akalın, 2012, p. 89). Today, indeed, it is almost impossible to reveal exactly why people in refugee camps in southern Turkey migrated. Considering that the individual evaluates the pushing factors of the geographic and social environment and the attractive factors of the place where s/he can move, it is understood that the individual's preferences and personal expectations from migration are important in the decision of migration (Göker, 2015, p. 39-40). However, the distinction that is intended to be made here leads to a dangerous and unrealistic abstraction, as the act of migration is completely outside or within the will of the individual. In other words, "...it is misleading to define every migration made due to socio-economic reasons as voluntary migration, and it can be equally misleading to define forced migration as a flight that occurs only as a result of war, conflict, or natural disaster" (Tuzcu, 2008, p. 1). Referring to the difficulty of classifying these phenomena, Faist (2003, p. 48) also emphasized the importance of questioning whether the villagers fleeing the drought in the Sahara are voluntary migrants or forced migrants, or whether the migrants trying to get rid of the high unemployment rate in their homeland are fully voluntary migrants. It is debatable how useful and meaningful it is to try to determine exactly how many of the immigrants, who are buried in the salty waters of Mediterranean almost every week are volunteers nowadays. In the rapidly globalizing world of the 21st century, these distinctions have become more controversial than ever. Instead of taking the compulsory-voluntary distinction as a dichotomy, possibly it is more meaningful to think that the degree of freedom extends from high to low, from reluctance or necessity to voluntarism (Faist: 2003, p. 49).

The Republic of Turkey has experienced the largest migration influx in its history in the past 10 years. Today, Turkey ranks 1st in the world as a developing country hosting approximately 4 million forced migrants, of whom about 3.6 million are Syrians under temporary protection, and approximately 400,000 are refugees and people of other nationalities with asylum status (UNHCR, 2019, p. 1). Although Turkey's transformation into a country of immigration, a transit country in the 1980s, and a receiving country in the 2000s, since its establishment, is a periodization practice frequently used in the literature, Anatolia has a thousand-year migration history with very different experiences due to its location. Although the quality and quantity change and transform in the historical process, human mobility, which is always in a state of flux, is inherent in the structure of this geography. For this reason, it is important to understand that Turkey, which has hosted the highest number of forced migrants in the 21st century, is also a country of migration historically. However, in this article, it is rather difficult to point to the entire incoming, passing, and outgoing flow also all phases of the thousand-year history of migration. Consequently, in this article, which attempts to understand human mobility towards Turkey, the pre-republican and republican period migration movements, which seem essential to capture a holistic perspective, are summarized and the changing position of Turkey in the international migration order is emphasized. Based on current research, reports, and statistical data, the study strives to better understand the possibility and sustainability of social cohesion and integration in Turkey in a global world characterized by risks, uncertainties, and pursuits in the final analysis.

\section{Pre-Republican Migration Movements}

Tekeli (2008, p. 142) describes the characteristics of the forced displacement movements of the classical Ottoman order in the 16th century; being a centralized autocratic country, striving for continuous growth around the principle of gaza (holy war in Islam), determining both the control of the surplus product and the military power of the Empire, and allowing different religious groups 
to live together without jeopardizing the integrity of the Empire. In this period, when individual rights were not institutionalized, the Empire institutionalized the forced displacement of people with the "exile" system (Tekeli, 2008, p. 144). In the 17th and 18th centuries, there were changes in the settlement policies, and in this period, the settlement of nomadic communities gained importance. With the settlement of the Yoruk, Turkmen, and Kurdish tribes from the West to the East and the Arab tribes in the south of Anatolia, the aim is to increase agricultural production and to ensure security within the borders of the Empire. In the 18th century, it is seen that voluntary displacement due to the developments in the economy and foreign trade and forced displacements in consequence of the settlement of the tribes came to the forefront. In the 19th century, in addition to the mass Muslim-Turkish movements coming from the lands separated from the Empire, developments such as private property rights, increasing capitalist relations, restrictions on the absolute authority of the sultan, regulations that facilitated the flow of goods, capital and human capital brought about the voluntary movement of population and the decrease in state's role and changes in the implementation of the resettlement policy (Tekeli, 2008, p. 146-149).

One of the preliminary groups that come to mind when it comes to migration or migrants is the Romany, which is an integral part of the Anatolian migration history. Although the concept of Romany is widely used in the international literature compared to the concept of Gypsy due to its negative connotations, it is also stated that the word "Gypsy" should be used precisely in terms of "return of dignity". Yet, these prejudices induce severe racism against these groups or individuals in many parts of the world. Gökçen $(2015$, p. 37) stated that although the fact that they are in a constant state of migration is overemphasized, the fact that there are many places where they "put down roots" is often ignored in current discussions. He also indicates that Anatolia and Thrace are geographies that are acquired "home" by them and played an important role in shaping their cultures (Gökçen, 2015, p. 37). The Romany left India and migrated to Anatolia under Byzantine influence, passing through the territory of today's Iran and Armenia, and then the Balkans hosted the Romany for four to six centuries. The Ottoman Empire made a place for themselves in the palace environment and the army with their craft and skills (Gökçen, 2015, p. 39-43). Today, the Romanies are an integral part of the Anatolian mosaic with the Rom, Dom, and Lom groups. Compared to the Lom living in the Eastern Black Sea Region and the Dom living in the Southeastern Anatolia Region, it is possible to say that the Rom groups living in the western parts of the country are the most well-known Romany groups (Kolukırık, 2008, p. 154). Although academic studies towards a closer understanding of these groups have increased in recent years, the need for policies to improve their disadvantaged positions and socio-economic conditions has not decreased.

Another group that used Anatolia as a frequent destination and made a homeland for a long time has been the Jews. Although it is known that the Jewish presence in Anatolia dates to the Roman Empire period, the most prominent contact between Turks and Jews in history was the freedom of religion and conscience granted to Jews fleeing from Byzantine oppression during the Seljuks period. Since then, when we take into account the migration of Ashkenazi Jews from Europe in the 14th and 15th centuries, migration of Sephardic Jews from Spain and Portugal, migration from Apulia, Bohemia, the Netherlands and Podolia (Poland), migration from Southeast Europe, the Balkans, Central Europe, and Russia during the Ottoman Empire and migration experienced in the years of modern Turkey and the Second World War, Turkey has often been an accredited country for Jews (Güleryüz, 2015, p. 50-70). Furthermore, the effect of Jewish refugees, including scientists, artists, and philosophers, who took refuge in Turkey upon the start of the Nazi regime in Germany in 1933 on the Turkish understanding of art and science is very noteworthy (Durugönül, 2013, p. 415).

When we look at the migrations from Africa to Turkey, the forced migrations that took place mostly through the institution of slavery in the four-hundred-year period between the 16th century and the First World War were replaced by voluntary African migrations, which intensified rapidly especially after 2000 after a gap until the 1990s (Şaul, 2015, p. 77-78). Following the Ottoman- 
Russian Wars in 1787 and 1828-29, as a result of the narrowing of the Ottoman borders in the Caucasus and the expansion of the Russians, over 1 million Circassians had to leave their homeland and seek asylum in the Ottoman Empire, also known as another forced migration, called 1864 Circassian exile (Kaya, 2015, p. 140-141). In the same period, the migration of Crimean Tatars and Nogais, which reached massive dimensions after the Crimean War, lasted for nearly two centuries in waves, and Crimean Tatars and Nogais also benefited from practices such as land allocation and tax exemption, as with other migrating groups (Yakut, 2015, p. 122-130-131).

The mass migrations that emerged in the countries that separated with the disintegration of the Ottoman Empire and established a nation-state were directed to the Ottoman lands in consequence of some military, political, economic, and social concerns. It should not be forgotten that these developments paralleled the process of nation-statization and the modernization process that required social, economic, and cultural reforms in the 19th century:

"While the social and political structures were changing, the fact that mass migrations coincided with the same period accelerated these changes and transformed the social structure of the society. ...These immigrants not only changed the demographic structure but also led to social, political, ideological, and economic changes. For this reason, the role of migration, forced or not, in the transformation of the Ottoman Empire and in the formation of today's Turkey cannot be denied (Kale, 2015, p. 167)".

As a result of the successive Balkan Wars, the First World War, and the National Independence War, migrations took place from every piece of land separated from the Ottoman Empire to Anatolia and from Anatolia to the new nation-states, especially the Balkans. When the dust settles, the population composition and ethnic structure of Anatolia changed significantly (Tekeli, 2008, p. 155158).

\section{Republican Era Migration Movements}

Tekeli (2008), who stated that the displacement movements experienced due to the people's dependence on the land before industrialization would not take place without their will that is, not voluntarily, hence this could only be the case in modern industrialized societies, concludes that migration is a concept of modernity. Therefore, based on the pre-admission that the phenomenon of migration is closely related to the modernization process, it qualitatively analyzes the one hundred and fifty years' period from the middle of the 19th century, when the humble Ottoman modernity began to develop, to the present, under four migration categories. The first of these categories is Balkanization migrations covering the years 1860-1927, the second is rural-urban migrations covering the years 1954-1980, and the third is inter-urban migrations that became dominant after 1975. The fourth category is related to the concept of life routes, which he put forward based on the fact that people change places immensely nowadays (Tekeli, 2008, p. 43-44).

Another periodization practice that can be put forward while historically examining the migration flows towards Turkey and from Turkey to other countries is follows as 1923-1960, 1960-1980 and after the 1980s (Eder, 2000; İçduygu, 2008 cited in İçduygu \& Biehl, 2012, p. 9-10). According to İçduygu and Biehl, the results of the "Turkification" policies carried out by the state to create a culturally, linguistically, and religiously homogeneous "Turkish" society in the period between 1923 and 1960, which covers the first stages of the nation-state establishment, can be seen. The rate of non-Muslim minorities, which was 19 percent in 1914, was calculated as only two per thousand in 2005 (İçduygu \& Biehl, 2012, p. 10-11). Undoubtedly, international developments have a role in this change as well as domestic policy dynamics. Although the migrations caused by the homogenization of the populations of the nation-states continued in the period between 1960 and 1980, labor migration from rural areas to cities and abroad with increasing urbanization characterized this period. In consequence of family reunifications and asylum applications after the labor migration abroad, Turkey has maintained its position as a country of emigration for a long time. However, after the 1980s, Turkey started to become a frequent destination for migrants whose ethnic or religious identity is not Turkish and started to meet the phenomenon of 
"foreigners" coming to or passing through Turkey (İçduygu, 2004; 2008 cited in İçduygu \& Biehl, 2012, p. 13).

Many different periodization studies regarding the migration movements of the Republic period in the context of irregular migrations, forced migrations, migrations from rural to urban areas, or external migrations show us that the history of the Republic of Turkey, as the history of civilizations, is a history of migration. Migration, which is a natural necessity of the construction of the Republic, industrialization, and development, has affected the social change process as a tool of social mobility in a way specific to the changing conditions of each period. Although the intensity of migration movements from rural to urban has changed from time to time since the establishment of the Republic, it has a regular flow. However, in this process, two important waves stand out in terms of reasons and motivations for migration. The first of these is the movements in the 19501970 period that started after the mechanization in agriculture, and the other is the movements in the 1980-1990 period, which was seen as a result of the attractive factors in the cities (Levent, 2019, p. 118-119; Özdemir, 2012, p. 2-10).

Especially beginning from the 1950s, due to internal migrations caused by rapid population growth, land fragmentation by inheritance, and intensive agricultural practices occurred in Turkey's demographic structure. Yalçın (2004, p. 115-117) summarizes dynamics affecting internal migration in Turkey as technological transformation in the rural structure, the rapid development of industry in some cities, rapid population growth, repulsive reasons for the village and attractiveness of the city, blood feuds in the countryside and terrorist incidents. As Güçlü (2002, p. 27) pointed out, urbanization movements that emerged in behalf of all these developments are a contemporary phenomenon that became visible after the 1950s in Turkey, as in many developing countries. With the change in the nature of the state, development and the welfare of the people have formed the basis of population displacements within the understanding of the welfare state, and the importance of settlement in cities has increased with the acceleration of urbanization (Tekeli, 2008, p. 160-163).

After 1970, cities in the West became more attractive due to the increase in industrial capacity, social facilities, and communication tools. They offer a relatively safer life. Since the establishment of the Republic, the population of Turkey has increased approximately six times. The rural-urban population balance, which is proportionally similar, has changed considerably since the 1950s. While the share of the urban population in the total population was $25.04 \%$ in 1945 , this rate was $77.30 \%$ in 2012 (SSen, 2014, p. 252). Although some different push and pull factors have come into play periodically, the primary motivation of rural-urban migration in Turkey is the decrease in agricultural value-added parallel to the increase in urban employment opportunities. Similarly, in a very recent study, a negative relationship was found between the ratio of rural population to the total population and urban employment and a positive relationship between agricultural added value (Aktaş \& Şahin, 2019, p. 232). In recent years, although the migration movement and migration effectiveness in Turkey differ between years, it is seen that the positive effect is especially evident in the western regions, and Istanbul, West Marmara, Aegean, East Marmara, and West Anatolia are the leading ones (Ünal, 2019, p. 755,737).

On the other hand, we see that lifestyle migration, which has been influential in the world, especially in the 21st century, has recently taken place in Turkey. Urban conditions resulting from the spatial and social transformation in the demographic structures of metropolitan cities direct individuals to smaller cities that are relatively safe, have a low population density, and have a higher quality of life (Kızltepe, 2020, p. 64). In this context, different trends emerging in urban life, especially ecological lifestyle, shape rural-urban, urban-rural, and rural-rural migration models. As a result of the national quarantine practices due to the Covid-19 pandemic, many households preferred not to return to metropolitan cities after the summer period. There is a possibility that this temporary preference may become permanent in the post-corona period. 
The Republic of Turkey has been the target or route of international migrations and human mobility within its lands since its establishment. Although the quality and quantity of human mobility towards the country has changed over time, it has become an integral part of the international migration order due to its geopolitical position. The study of Levent (2019, p. 120), which makes a chronological list of migration waves to Turkey, presents an excellent picture for understanding the human mobility that has come to Anatolian lands since the establishment of the Republic and its effect on the demographic structure. Accordingly, with the population exchange agreement of 1924, approximately 500,000 people from Greece settled in the country's rural areas in the northwest. Between 1924 and 1950, 305,158 people from Yugoslavia and Macedonia settled in the cities in the north of Thrace. Between 1925 and 1979, 491,582 people from Bulgaria in three different waves mostly settled in rural areas, and about 800,000 people who came with the 4th Wave in 1989 settled in the cities. In 1979, about 1,000,000 people from Iran turned towards metropolitan cities, especially developed cities in the West and Southwest. In recent times, although the overall numbers are not known, it is seen that the migration waves from Uzbekistan, Uyghur Autonomous Region, Kyrgyzstan, Kazakhstan, and especially Afghanistan exhibit a similar settlement pattern. As a result of the Gulf War, 519,031 refugees from Iraq moved to the cities in the West and Southwest. It is seen that approximately 48,000 immigrants from Bosnia, Kosovo, and Macedonia entered the country between 1992-2001. Lastly, although the history of migration movements from Syria to Turkey dates back to 1945 , there is no clear information about the rates before 2011. However, 3,666,059 asylum seekers who came after 2011 preferred to stay in cities close to the border and metropolises (Levent, 2019, p. 120).

As can be seen, Anatolian lands have a substantial history in terms of their location in the context of forced migrations. Anatolia's memory of forced migration expanded considerably during the First World War, between the two world wars and the Second World War, which passed with "dispatch", "exchange" and "deportation". Between the years 1950-1990, Turkey became one of the target countries of forced migration, primarily as a result of the Cold War policies, and after the deterioration of the bipolar order, it continues to be the addressee of the forced migrations brought about by regional problems such as Bulgaria, Bosnia, Kosovo, Iran, Iraq and today Syria (Özgür, 2012, p. 200-211).

It is widely stated that Turkey has turned into a country of immigration and/or transit from being an emigrant country with the changing conditions after the 1980s. It is possible to say that the ongoing environment of conflict in the Middle East is largely effective among the reasons behind this change (İçduygu \& Biehl, 2012, p. 15). Regulations in Turkey are based on the United Nations Convention Relating to the Status of Refugees, signed in Geneva in 1951 and entered into force in 1954. Following the updates made with the 1967 New York Protocol, the regulations regarding migration and asylum movements are based on the 1994 Asylum Regulation, and in this context, the distinction between refugees and asylum seekers creates a distinction based on quantity, quality, geography, and time (Kartal \& Baş̧̧, 2014, p. 282-283). At this point, Turkey mostly becomes a transit country for those who want to reach the West due to the "geographical limitation" it has put into the 1951 Geneva Convention. Accordingly, Turkey only grants asylum to people of European origins and only gives temporary asylum to those coming from Africa and the Middle East. For this reason, it is stated that most individuals coming from these regions either moved to Europe or returned to their countries after staying in Turkey for a certain period. According to the General Directorate of Migration Management of the Ministry of Interior:

"Turkey accepted the 1951 Geneva Convention by ratifying it in the Turkish Grand National Assembly with the Law No. 359 on 29 August 1961. However, considering its geopolitical position, Turkey has used its right of choice to determine the refugee status and stated that it will only accept individuals who come to Turkey from Europe and seek international protection as refugees under the contract (Migration Report, 2016, p. 75)." 
In this context, refugee, conditional refugee, and subsidiary protection statuses are given if the requests of those who request international protection from Turkey are evaluated positively. The majority of asylum seekers in Turkey are Iraqis and Iranians in the past, and Syrians and Afghans in recent years. It is possible to say that African asylum seekers, who are always relatively few, mostly come from North African countries, and that those coming from Central and West African countries generally do not apply for asylum, which increases the rate of illegal economic migration (Yükseker \& Brewer, 2010, p. 300).

It is avowable that Turkey continues to experience the consequences of "being in a geography affected by almost all forms of migration movements" (Ünver, 2009, p. 86). If we periodize Turkey's irregular migration history, it is possible to talk about the existence of four different periods: the emergence period covering the years 1979-1987, which was especially affected by the influxes after the Iranian revolution; maturation period covering the years 1988-1993, revealing different types of migration such as asylum, transit migration and circular migration; with the increasing amount of irregular migration, the saturation period between 1994-2000/2001, when national regulations were tried to be harmonized with international regulations, and finally, the institutionalization period extending from 2001, when irregular migration, human trafficking, and human smuggling issues heavily occupied the country's agenda (İçduygu, 2005; İçduygu \& Sert, 2012 cited in İçduygu, 2015, p. 281). In this context, Turkey has been a transit country for migrants from Central and Western Asian, Middle Eastern, and African countries, and a target country for migrants from former Iron Curtain countries.

Since the 1990s, there has been a severe increase in the number of irregular migrants coming to Turkey from the Balkans and former Soviet countries. "About 25\% $(177,000)$ of the 763,000 people arrested in Turkey between 1996 and 2008 were the citizens of Armenia, Azerbaijan, Bulgaria, Georgia, Moldova, Romania, Russian Federation, and Ukraine" (İçduygu \& Biehl, 2012, p. 25). Statistical data in recent years also show that this trend is in progress. The number of irregular migrants apprehended in 2015 increased by 150\% compared to 2014 and reached 146,485. Thus, the number of irregular migrants apprehended between 2005 and 2015 was 643.397, and the number of people apprehended as migrant smugglers within the scope of irregular migration was 4.471 (Migration Report, 2016, p. 64-65). At the end of this process, it is stated that the migration regime in Turkey institutionalizes the country by defining it as a country that receives migration and provides a transit area for migration (İçduygu, 2015, p. 282). In other words, it is necessary to understand the changing position of Turkey from the source country to the transit and then to the target country.

\section{Turkey's Changing Position on the Global Migration Map}

The economic, demographic, and political developments experienced in Turkey in the 2000s have not only changed Turkey's position in the global economic and political order but also made it one of the main immigration countries (Düvell, 2020, p. 18). The relatively high political stability experienced is the basic dynamics of this change in the position of the economic growth and the liberal visa regime (Düvell, 2019, p. 2227). Current developments indicate that Turkey's position on the global migration map has changed, that the irregular migration flow towards developed countries, especially EU countries, in the East-West and South-North axis has become one of the intense passing corridors and the influx of asylum seekers is increasing (Kartal \& Başç, 2014, p. 293). On the other hand, in addition to the traditional target countries such as the EU, another target country zone has emerged, for example, stretching along the southern edge of the Mediterranean, from Morocco to Turkey, Russia, and Kazakhstan. One of the main target countries of the three incoming flows coming from the four types of sending countries in this region (1st Group: Belarus, Turkmenistan, Uzbekistan, Tajikistan, and Kyrgyzstan; 2nd Group: Moldova and Ukraine; 3rd Group: Azerbaijan, Armenia, and Georgia; 4th Group: Syria) is Turkey (Düvell, 2020, p. 19-20). 
In addition to these mobilities, we can talk about the existence of migrations from Europe to Turkey, especially the backward migration of European citizens of Turkish origin. Migration from Germany to Turkey numerically exceeded the migration from Turkey to Germany as of 2006 and remained negative for the next five years (Sirkeci et al. 2012, p. 377-378). Although the backward migration of European citizens of Turkish origin played a major role in the emergence of this statistic, the migration of European citizens to Turkey also has a share. In this context, Balkır \& Kaiser (2015) extended the study of Suzan Erbaș (1998) based on German migrants to include citizens of other countries of the EU and presented a complementary classification. According to this study, the groups living in Turkey are as follows:

a) Officials and representatives of EU or foreign companies or institutions,

b) EU citizens whose spouses are Turkish citizens,

c) Children of EU-Turkish families formed by mixed marriages,

d) Retired EU citizens,

e) EU citizens seeking an alternative lifestyle,

f) EU citizens of Turkish origin,

g) "Bosphorus Germans"

h) Refugees -especially those who came from Germany within the framework of the Nazi regime- (Balkır \& Kaiser, 2015, p. 225-226).

The Europeans, who have been called "Levantine" since the Ottoman Era, have carried out their commercial activities freely through privileges they have, so they have continued their existence in Anatolian lands for many years. Under the liberal economic policies put into practice since the 1980s, the commercial relations that emerged as a result of Turkey's becoming attractive for foreign capital brought along the highly qualified immigrants, also known as "transnational elites". In addition to this group, which is evaluated in the context of migration from Europe to Turkey, Özbek (2010, p. 161) mentions the existence of two other groups: The first group consists of retirees who want to spend the "evening of their lives" in Turkey, citing cheap living expenses, mild climate, and attractive nature, and the second group is cultural pessimists who are critical of living conditions such as the inhospitality and materialism they claim to exist in their own country. In the 2000s, Turkey, along with Greece and Croatia, was added to countries such as Spain, Portugal, and Italy, which are traditionally preferred for the type of migration that is referred to as international retirement migration or post-retirement migration in the literature (Özerim, 2012, p. 4767). As in many other countries, retirement migrations in Turkey have chosen touristic settlements with more preferred climatic conditions. Nowadays, the towns and districts on the Mediterranean and Aegean coasts have a considerable retired European population.

However, the migration flows that change Turkey's position on the international migration map does not come from the West. Basically, most of the international migration towards Turkey comes from neighboring countries or distant countries of Asia and Africa (Kolukırık, 2014, p. 37). Turkey, where migration, asylum, and temporary protection have become an important component of the political literature and the agenda, has been accepted as one of the central countries of forced migration, especially with the mass Syrian migration after 2011 (Tanrikulu, 2020, p. 11; Nizam \& Rose, 2019, p. 98). The tent cities of Altınözü on June 9, 2011, and Boynuyoğun on June 12, 2011, were established due to the ongoing waves after the group, which came as a result of the first mass population movement from Syria to Turkey on April 29, 2011, was settled in the center of Yayladağ, the first tent city area. In the following period, the pronounced red lines regarding the number of asylum seekers had to be revised many times. Moreover, in addition to the fact that the occupancy rate of the camps has reached $100 \%$, there has been an incalculable increase in the number of refugees in non-camp areas. In the three-and-a-half-year period from April 2011 to December 2014, the number of refugees reaching 1 million 650 thousand in total has been recorded as a forced migration movement of unprecedented magnitude in the world (Erdoğan, 2014, p. 5-9). "In 2015, 984,263 Syrians were registered and as of the end of the year, the number of biometric registrations of Syrian citizens who were placed under temporary protection was 2,503,549" 
(Migration Report, 2016, p. 85). This number has exceeded 3 million as of 2017 (Migration Report, 2017, p. 71), while the number of Syrians under temporary protection has reached 3,643,769 as of January 2021 (Association of Refugees, 2021).

Turkey has maintained its "open door" policy from the very beginning of this process and has put those fleeing the conflict and war environment under "temporary protection". The fact that neither Western states nor international organizations took initiative other than symbolic aid to share the burden of the human tragedy has resulted in that neighboring countries, especially Turkey, must shoulder the financial and humanitarian burden of this crisis, which lasted much longer than expected and still continues. The General Directorate of Migration Management stated that the international protection applications of Syrians who came to Turkey for protection purposes due to the internal disorder in Syria are not included in the scope of temporary protection since it was not possible to evaluate them individually, and therefore could not be reflected in the international protection application statistics (Migration Report, 2016, p. 76).

The forced migration of Syrians, which has been one of the main topics of discussion in Turkey's agenda in recent years, has an important position from the others, although it is not the first mass refugee case in Turkey's migration history. In 1989, many of the Turkish and Pomak origin migrants from Bulgaria returned to their homeland after the collapse of the communist regime, and migrants from Northern Iraq returned to their homeland after the creation of a "safe zone" and strengthened the relations between the two countries. However, it was understood that the prediction that a similar process would occur concerning the Syrians was wrong, and the migrations that started as a result of increasing political pressures, together with the start of a terrible civil war, witnessed an unprecedented massive refugee situation in history. One reason for the significant increase in the number of asylum seekers in Turkey in the recent period is the opendoor policy implemented together with the country's proximity to refugee-sending countries, and another reason is undoubtedly the strict "securitization" policies of other countries in the region, which include combating migration. As Alagöz and Demirkıran (2020, p. 206) stated that while migration was considered one of the low policy issues in the bipolar world order, it has turned into a high policy issue within the scope of security with the end of the bipolar world system.

After the terrorist attacks of $9 / 11$, this approach towards migration and security phenomena has become increasingly rigid in the 21st century. Since 2007, the number of refugees who have left their homes due to conflict and violence has doubled and exceeded 25 million. Migrant flows in the Mediterranean between 2014-2019, on the other hand, are one of the biggest waves that the European Union has faced since its establishment (Camarena et al., 2020, p. 1). "Migration as a securitized area" has also manifested itself as a "Fortress Europe" approach in the EU. Undoubtedly, Turkey and EU member states were primarily affected by this policy (Zorlu \& Yetim, 2020, p. 342). It is known that securitized migration policies are possible with the "externalization" method. In other words, the EU is trying to solve the problem of globalized refugees and asylum seekers out-ofdoors, in other geographies (Kolukırık, 2014, p. 51). Policies focused on securitization and externalization intensified as a result of the Arab Spring and the Syrian Civil War have increased the importance of Turkey, which is an EU stronghold in the eyes of the EU. Due to the rising border barriers and tightening border controls, the rate of resorting to illegal methods has increased considerably, and in parallel with this, human smuggling and trafficking have become institutionalized and increased exponentially in Turkey. In 2015, when refugees who lost their lives in the salty waters of the Mediterranean almost every day became a routine part of the media's daily schedule, record numbers of irregular migration and the influx of asylum seekers were recorded. Of the 1,008,616 refugees who crossed the Mediterranean and reached Europe that year, 851,319 , or about $85 \%$, reached Greece by crossing the Aegean Sea through Turkey. When 3300 people crossing from Turkey to Greece and 30,000 people to Bulgaria are added, it is clearly understood that Turkey is the main route of the refugee influx towards the EU (UNHCR 2016b, cited 
in Düvell, 2019, p. 2228). On the other hand, 2.503,549 Syrian citizens were taken under temporary protection only in Turkey in the same year (Migration Report, 2016, p. 85).

After the Readmission Agreement and Visa Liberalization, which was signed in pursuit of a more balanced reconcilement, it was once again understood that the EU "doesn't fulfill its responsibilities adequately and protects its borders on the basis of the responsibilities it imposes on Turkey" (Şemşit \& Çelik, 2019, p. 291). The EU's top-down migration management practice which is based on the EU's efforts to categorize populations according to their countries of origin and to prevent nonEuropeans from entering the EU with a biogeopolitical approach (Jauhiainen, 2020, p. 262), has narrowed Turkey's space of action and directed it to different policies. In 2016, the number of people crossing from Turkey to Greece decreased by $90 \%$, and migrants head towards other routes to the EU. The Libya-Italy route was the most preferred one in 2017, and the Morocco-Spain route became the most preferred one after strong preventive measures. Then, in 2019, the Eastern Mediterranean route from Turkey to Greece appears to be the commonly preferred route again (UNHCR 2019b; 2020; cited in: Jauhiainen, 2020, p. 262).

Therefore, although Turkish foreign policy initially focused on ideological and pragmatic goals on a different axis from the securitized policies towards mass migration from Iraq, it has experienced a rapid return to a security-oriented policy strategy as a result of international circumstances (Altiok \& Tosun, 2020, p. 699). Implementing "migration diplomacy, in which immigration is used as a coercive tool against the Union" (Zorlu \& Yetim, 2020, p. 343), Turkey's opening its doors to voluntary crossings in February 2020 resulted in migrants moving to European borders, and a new humanitarian crisis was added to the time course. However, the Covid-19 pandemic, which followed this case, caused all other agendas to be left behind for a while, both on a national and global scale.

\section{Integration and Adaptation Continuum After a Decade}

The changing migrant profile, which is one of Turkey's changing positions on the international migration map, detailed in the previous section, necessitated a change in the perception of the culture of living together. However, in this process of change, the 'geographical limitation' put into practice due to security concerns and the short-term legal statuses created in connection with it, seem to have prevented the changing social reality of integration and coexistence from being understood in practice and the daily political climate. In other words:

\footnotetext{
"The fact that those who are accepted as migrants are similar to the general population profile of the country on the basis of ethnicity, and those who are accepted as refugees are quite limited in quantity has led to the fact that the experience of living together with the Turkish society of those who came with international migration has been ignored until recently (Nizam \& Gül, 2019, p. 98)."
}

However, with the realization that Syrians under temporary protection are more likely to stay longer than expected, many political and legal arrangements have been made since 2013. At the same time, this process has witnessed ups and downs brought by the technocratic and politicized approach in migration management, as mentioned in the previous section. However, as of today, Syrians with their uncertain status have already lived with Turkish society for ten years. For this reason, it is a priority issue to accept that international migration, refugee, and asylum-seeking issues in Turkey are now the subjects of the international human rights regime, beyond "Turkish Hospitality" or "Hospitableness" as it has been explained for a long time (Ünal, 2014, p. 86). Therefore, Alagöz and Demirkıran (2020, p. 230-231) indicate that "minimizing the negative consequences of the mass migration influxes caused by the Syrian crisis in Turkey, can be possible with a paradigm change that Syrian migrants are not completely temporary but partially permanent". Moreover, it is a highly controversial issue whether Syrian migrants, which we can define as foreigners in the context of legal status, can be defined as sociological "foreigners" due to the historical, social, political, and economic interaction between the two communities (See: Nizam \& 
Gül, 2019, p. 98). Studies conducted on the level of social acceptance in earlier periods give some clues in this context. For example, Erdogan $(2014$, p. 123) conducted research that revealed the relations and dynamics of the Syrians living together with the Turkish society. More than $87 \%$ of 1 million 650 thousand Syrians live outside of the camps all over Turkey. The results of the study claim that the level of social acceptance in Turkish society regarding the Syrians, who had been among them for 3.5 years at that time, was extremely high (Erdoğan, 2014, p. 126).

However, what exactly is meant by the expressions of social acceptance and harmony here, in other words, whether it is shaped within the framework of which dynamics or whether it is sustainable is quite controversial. As it is known, integration is a long process in terms of economic, social, and cultural aspects that includes both the host society and the immigrant society. On the one hand, this process is shaped by the efforts of immigrant communities to exist in the new social structure by preserving their original identities and cultures. On the one hand, it is shaped by the host society's historical and socio-cultural approach to what is different and to what extent this can turn into an inclusive and integrative attitude. At this point, we can say that the integration process is built on social acceptance in the host society and on the desire for integration in the immigrant community. The main factor that interrupted this mutual social acceptance and harmony desire in Turkey has been the temporality-permanence problematic. Therefore, it can be specified that the external factor that affects the length of the adaptation process is the perception of "temporariness" or "sojourn".

As explained in the previous sections, the reason for characterizing this factor as external is that the securitized policies prevailing in the current international migration regime and the Syrian Civil War, which lasted longer than expected, lie behind Turkey's position and migration diplomacy that it uses as a coercive tool in foreign policy. We can say that this main external factor, which negatively affects the adaptation and integration process, was effective at the beginning of the 10year period. The main negative internal factor that increased its effectiveness at the end of this process (and can be predicted to increase even more in the post-corona period) is the direct and indirect effects of mass migrations on the labor market, which is popularly called "they are taking our jobs".

According to the data of the General Directorate of Migration Management, only $1.6 \%$ of approximately 3.6 million Syrians live in temporary shelters (goc.gov.tr/gecici-koruma) and their economic situation constitutes the weakest part of society according to the Grand National Assembly of Turkey Migration and Integration Report (2018) (cited in Kaya and Çolakoğlu, 2020, p. 599). Mainly, $64 \%$ of Syrian households living in cities live below the poverty line and $18 \%$ live below the extreme poverty line (Özvarıș et al., 2020, p. 2). Although 1.4 million Syrians currently receive unrequited cash support for basic needs such as rent and food, this support is undoubtedly not enough to provide quality living conditions. Although refugee status is required for access to health services, Syrians under temporary protection also have health insurance according to the relevant legislation and can benefit from these opportunities free of charge in the city they are registered (Özvarış et al., 2020, p. 2). Studies on the demographic data of Syrians show that the Syrian population is younger than the host population and this is important for the labor market and access to education services. It also shows that the distribution of Syrians to different cities by years and migration patterns are shaped according to the characteristics of the labor market and cultural similarities (Adalı \& Türkyılmaz, 2020, p. 212).

We can say that the negative effects of migrants on the labor market and the economic condition of the country lie at the root of the negative attitude of the Turkish people towards immigrants, which is important in terms of social acceptance and harmony. According to the 2013 Transatlantic Trends Survey, $54 \%$ of the Turkish people define migration as a problem, while only $18 \%$ see it as an opportunity. The rate of those concerned about illegal migration is $69 \%$, and the rate of those worried about legal migration is similarly $60 \%$. It is well understood that approximately two-thirds of Turkish society have apprehension and concerns about immigration (Transatlantic Trends, 2013, 
p. 48). On the other hand, $77 \%$ of the respondents to the Social Trends Survey conducted in 2015 think that asylum seekers harm the economy, $68 \%$ think that they take their jobs away, while only $16 \%$ think that they enliven the economy (GLOBAL, 2015, p. 42 cited in Güder, 2016, p. 132). According to the results of the Turkey Trends Survey for 2019, the complacency rate from Syrian refugees decreased compared to previous years and became $12.9 \%$. Among the reasons for this rate are the thoughts that they are prone to crime, disturb the peace of the society, and increase unemployment because they provide cheap/illegal labor. However, it is also seen that the rate of those who think that asylum seekers will not return to their countries has increased to $70.9 \%$ (Turkey Trends, 2019).

Undoubtedly, mass migrations can directly or indirectly affect the labor market. However, considering the structure and characteristics of employment in the country, it is not easy to reveal a causal relationship that will distinguish this effect from other factors. Nurdoğan \& Şahin $(2019$, p. 2201) examining the relationship between the number of foreign people living in Turkey and unemployment between the years 1995-2019 using the time series analysis method, concluded that the increase in the number of foreigners directly or indirectly increases unemployment. However, as stated in the study, this causality relationship may be due to the unemployment structure in the Turkish labor market and/or the qualitative structure of the migrant workforce (Nurdoğan \& Şahin, 2019, p. 2216). Likewise, in countries such as Turkey where the informal sector is widespread, the substitution of migrant labor with domestic labor can be realized much more easily. According to Dedeoğlu (2018, p. 37),

"Even though immigrants' places of origin, gender, industries, and migration patterns change rapidly, the situation of migrant labor in the Turkish labor market takes two different forms. First, there is a concentration in jobs where domestic labor has a shortage of supply, such as household services, and the second is sectors such as construction, textile, and agriculture, where migrant labor competes with domestic labor and lowers the wage level."

Migrant labor is widely employed in agricultural production, which is one of the most laborintensive sectors, and especially in the harvesting of agricultural products. In other words, foreign migrants, especially Georgian, Azeri and Syrian, have been added to the local workers of different ethnic origins in the Turkish agricultural labor market. Thus, in this field, which is characterized by informality, insecurity, and temporariness, the stage of "competition of the poor from the watch of the poor" has begun (Dedeoğlu, 2018, p. 39, 64).

In-depth research specific to each sector and on a regional or even urban scale will make the picture of the multidimensional relationship between the mass migrations that Turkey is exposed to and the labor market much more understandable. However, macroeconomic indicators such as inflation, economic growth, and unemployment rates can be a suitable tool to understand the impact of irregular migration on the Turkish economy. According to the data of current research conducted in this context and covering the period of 2012-2020 (Tanrikulu, 2020, p. 1), migration from Syria to Turkey has contributed positively to the economy by increasing the demand for products in the market. The results also find that the Syrian population leads to an increase in inflation and unemployment. However, this effect can be reversed depending on how quickly migrants integrate into the labor market. On the other hand, despite the widespread belief that migrants increase the budget deficit, the findings point to the potential for migrants to increase tax revenues in the country - through increased employment, business ventures, production, and consumption activities. Likewise, companies with Syrian capital in Turkey currently constitute onethird of the total number of foreign companies established (Tanrikulu, 2020, p. 11). Therefore,

"Successful steps to be taken in terms of economic problems, poverty and unemployment indicators in Turkey will also reduce the reactions to the fact that asylum seekers are seen as individuals who increase poverty/unemployment. Moreover, measures should be taken to prevent refugees from being seen as cheap labor forces and to prevent them from being an unregistered and reserve labor force. (Kaya \& Çolakoğlu 2020, p. 607)." 
We can say that the media has a great influence on the framing of asylum seekers as the cause of poverty and unemployment in Turkey. Media that legitimizes the problem rather than contributing to the solution of the problem (Kolukırık, 2009, p. 14) with populist and superficial news headlines and texts about Syrians in the past years, and thus mediating disinformation and provocative discourse, should not be a tool for the spread of hate speech regardless of the volatile political climate in Turkey and should not interfere with the harmonization process. Demographic data, including the population projections of Syrians, is of great importance in terms of the sustainability of long-term policies such as health, education, and urbanization, as well as the economy. Coordination and cooperation between the actors are very important for the realization of social integration and harmony in the right way in practice. Likewise, in regions where the demographic structures of cities and the density of Syrians are quite different, local needs can differ greatly. For example, social integration practices in Mersin, where one-third of the population is Syrian in 2018, may take shape very differently from the practices in other cities.

\begin{abstract}
"In this context, municipal administrations appear as important institutions in terms of social cohesion and the provision of local services to immigrants. In the success of migration management, all departments related to migration should work in coordination and local governments should be seen as partners in solving migration-related problems (Cetin, 202, p.: 2039)."
\end{abstract}

Consequently, the most current problem that will negatively affect the harmonization and integration process in Turkey (as in many other socio-economic issues in the country) is the consequences of the ongoing Covid-19 pandemic. During the pandemic period, which was experienced for the first time by the global world with all its economic, social, political, and legal dimensions, the Covid-19 virus spread in a very short time, and it was not enough to prevent this spread by closing the borders of the countries completely. As a result of the rapid regression in the global economy, strong concerns about the devastating impact of the pandemic on the demographics and economy of countries have still been continuing. Research shows that Covid-19 deepens existing inequalities and reinforces conditions of precarity for migrant workers (Suhardiman et al., 2021, p. 88).

It is possible to predict that we will see the results of the change in the individual and social habits of the society in the post-corona period. In addition, with this experience of countries and the system, the concepts of human and collective security may lead to much debate, the structure of the labor market and social security conditions may need to be rearranged. A review of the structure of public administration, decision-making, and action mechanisms at different levels can be expected. All these changes are undoubtedly developments that will affect the international migration regime and national migration management policies. For example, India has experienced the second largest mass migration due to the Covid-19 pandemic in its history since the migration flow after the partition of the country in 1947 (Mukhra et al., 2020, p. 736). Similarly, high rates of reverse migration are observed in many countries due to the closure of borders, limited employment opportunities, concerns about the upcoming but unknown future, and financial crisis. It can be predicted that the reverse mass migrations triggered by Covid-19 will have far-reaching effects on national and international migration patterns, although it is not emphasized much at the moment due to different priorities among countries (Mukhra et al., 2020, p. 736-737).

On the other hand, "when serious global and national challenges, such as the economic recession or the COVID-19 pandemic, hit a country, the well-being of the displaced people is not a priority, as is the well-being of that country's own citizens" (Jauhiainen, 2020, p. 261). It is often seen that refugees and asylum seekers are neglected in such extraordinary situations, where the responsibility and scope of action of the state, as the main actor responsible for the safety and welfare of its citizens, is greatly increased. It can be estimated that the sensitivity of international institutions and organizations, which are very important in such periods, is lower than normal due to the different priorities brought by the pandemic. At this point, we can say that Turkey, which has surpassed all 
developed countries in humanitarian aid expenditures in recent years, is giving a good account of itself. It has been documented that many refugees in Turkey live in crowded housing conditions that may lack the necessary hygiene standards to prevent the transmission of Covid-19 (Özvarış et al., 2020, p. 6). Fortunately, Turkey seems to have taken advantage of the fact that asylum seekers have been granted access to public health services and the capacity of public health services has been increased in provinces with a high Syrian population. However, it is most likely that a different picture will emerge in terms of the socio-economic consequences of the pandemic.

Practices such as short and long-term quarantines, distance education and closure of workplaces carried out in Turkey as well as all over the world in order to prevent the pandemic and reduce the number of cases have led to the deepening of inequality in Turkey, as in the rest of the world. Those most affected by this are vulnerable groups, including refugees. The unemployment rate has increased considerably among asylum seekers who work in unregistered and insecure jobs for daily wages; children have fallen behind in distance education as a result of economic inadequacies that lead to the inability to access the necessary technological tools such as the internet, computer, and television. As a result, the social reaction brought about by the difficult economic conditions, increasing unemployment, and deepening poverty caused by the pandemic can easily lead to an increase in anti-immigrant sentiment and hate speech, resulting in wasted efforts for social cohesion and integration so far.

\section{Conclusion and Discussion}

People have always been on the move to escape disasters and difficulties or realize their dreams to achieve a better life. The elements that distinguish today's migration movements from previous ones and increase their importance are the scale and complexity of migration; its breadth reaching every end of the world; its dynamic structure that grows exponentially with information, communication, and transportation technologies. In conjunction with the intensification of globalization, each country has encountered different forms and rates of international migration and has produced and developed the way of meeting and directing this phenomenon in a manner specific to these experiences. It is possible to say that migration regimes that nation-states cannot control have become much more complex in the global world. While globalization foresees the free movement of human capital, at this point, as a result of security-oriented migration policies, states restrict the circulation of economic migrants. As a result of globalization and neo-liberal policies, they do not accept refugees who escaped from the conflict and poverty in their countries as refugees and push them to the illegal area. In today's world, where globalization has increased its impact in every field, it is of great importance to perceive migration as one of the leading providers of fair, inclusive, and sustainable social and economic development. The necessity of Western countries to create more shelters and opportunities for refugees and asylum seekers is undoubtedly real. However, more importantly, it is required to provide various funds and binding financial support to the states and private sectors of those neighboring countries (ones with a much larger number of refugees than EU countries) to create job opportunities.

In recent years, when international migration has been highly associated with national security, conflict, and disorder, it is seen that the anti-immigration discourses over the concept of security are mostly shaped by the fact that immigrants are a threat to national integrity, potential terrorists, and displace the citizens of the country from their jobs. These discourses increase considerably during the economic crises and election periods. Rising xenophobia, discrimination, and even racism with anger and insecurity cause the integration and multiculturalism policies to be questioned, and the social cohesion processes interrupted. The European Union developed largescale preventive and securitizing practices. These practices followed the Copenhagen School representatives' work on securitization. The chaos after the Arab Spring, the emergence of ISIS in the Middle East and North Africa, especially in Iraq and Syria, and its increasing popularity among young Muslims in Europe, strengthened the securitization of migration. The process of defining and relating to foreign communities within the Western countries cannot be thought of independently 
from the process of self-definition. Like many other formations, political formations set out from their reasons of existence and approach the other from this perspective while defining the other. Therefore, it can be stated that the current securitization discourse is a political choice rather than a real threat. At the beginning of the discourses underlying the securitization of migration and the strict border policies implemented accordingly, is keeping the danger of Islam away from the West. The discussion has shifted from cultural richness and freedom of belief to the field of national and public security. Terrorist incidents in the center of Europe and rapidly rising right-wing parties are indicators of the course of this discourse.

For this reason, new models are needed to understand the West's relationship with the other. It is evident that international migration flows due to domestic instability and conflicts, wars, terrorism, and climatic disadvantages such as drought and water shortage will continue in the coming years. Likewise, the economic-based international migration flows from poor regions to regions with a labor shortage.

Due to its location, we can say that Turkey will continue to receive its share from these flows for many years as a destination country and a country providing transit for migration. Likewise, very recent research on migration projections claims that Turkey will be one of the three countries with the highest net migration rates in 2100 (Vollset et al., 2020, p. 1298). It can be predictable that considering the risks and threats in the region such as ethnic and denominational conflicts, economic instability, anti-democratic regimes, environmental problems and related resource shortages, and the global struggle over energy resources will not disappear soon, migration flows to Turkey, whether a destination or a transit country, will proceed. When this foresight is considered together with the fact that Turkey is currently the country with the highest number of refugees among developing countries, it is possible to say that migration management, integration, and adaptation studies will be one of the main factors of Turkey's future domestic and foreign policy strategies. On the other hand, Turkey's idiosyncratic migration diplomacy, which sometimes deviates from time to time, does not seem to be a sustainable method in the long run. However, it is not only the West that needs new models in its understanding of the relationship with the other. As Bauman emphasizes, in today's world where "indifference is also globalized" like many other things, overcoming the "me and the other" discourse is the main element of managing the migration crisis. In Turkish society, where the phenomenon of migration and the concepts that meet this phenomenon (hejira, sorrow, longing, homeland, expatriation, homesickness, asylum, nomadism, diaspora, etc.) are already loaded with negative connotations in social memory and usage, the argument that what the migrant brings creates a more backward sociological structure than the settled, is at the source of the prejudice against migration and migrants (Parin, 2019, p. 688). One of the underlying reasons for this approach, which results in contempt and marginalization and thus inability to integrate, is the inability to look at migration from a historical sociological perspective with a retrospective approach. Although it is emphasized in the literature that the structure of Turkey's previous migration experiences is different and the experience of living with a foreigner, whether legal or sociological, is a new phenomenon, the migration culture of Anatolian lands and the flexible ground provided by this culture may enable Turkey to create a unique and sustainable cohesion policy. In this process, the impact of multifaceted social policies produced in accordance with the changing socio-economic structure of the post-corona world and prioritized according to the magnitude of vulnerabilities will be of great importance.

Peer-review: Externally peer-reviewed.

Grant Support: The author received no financial support for the research, authorship, and/or publication of this article. 


\section{References}

Adalı, T., \& Türkylmaz, A. S. (2020). Demographic data on Syrians in Turkey: What do we know? International Migration, 58(3), 196-219.

Akalın, A. (2012). Açık, döner, mühürlü kapılar: 20. Yüzyılda batı/doğu ekseninde emek göçünün seyri. T. Bora. (Ed.). Küreselleşme çağına göç: kavramlar, tartışmalar (pp.89-106). İstanbul: İletişim Yayınlarl.

Aktaş, E., \& Şahin, A. (2019). Harris-Todaro göç modeli: Türkiye örneği. Çukrova Üniversitesi Sosyal Bilimler Enstitüsü Dergisi, 28(1), 222-234.

Alagöz, B., \& Demirkıran, Y. (2020). Düzensiz göç, güvenlik ve politika: İran ve Türkiye örnekleri. Ortadoğu Etütleri, 12(1), 206-237.

Altıok, B., \& Tosun, S. (2020). Understanding foreign policy strategies during migration movements: A comparative study of Iraqi and Syrian mass refugee inflows to turkey. Turkish Studies, 21(5), 684704.

Balkır, C., \& Kaiser, B. (2015). Türkiye'de Avrupa Birliği vatandaşları. Türkiye'nin göç tarihi: 14. yüzyıldan 21. yüzyıla Türkiye'ye göçler (pp.221-241), İstanbul: İstanbul Bilgi Üniversitesi Yayınları.

Camarena, K. R., Claudy, S., Wang, J., \& Wright, A. L. (2020). Political and environmental risks influence migration and human smuggling across the Mediterranean Sea. Plos One, 15(7), 1-16.

Castles S. \& Miller M. J. (2008). Göçler çağı: Modern dünyada uluslararası göç hareketleri (Çev. B. Uğur Bal \& İ. Akbulut). Bilgi Üniversitesi Yayınları, İstanbul.

Çağlar, A. (2011). Türkiye'de sığınmacılar: Sorunlar, beklentiler ve sosyal uyum. Ankara: Hacettepe Üniversitesi Yayınları.

Çetin, Z. Ö. (2020). The international migration in Turkey and local governments. Business \& Management Studies: An International Journal, 8(2), 2019-2043.

Dedeoğlu, S. (2018). Tarımsal üretimde göçmen işçiler: Yoksulluk nöbetinden yoksulların rekabetine. Calışma ve Toplum, 56(1), 37-68.

Durugönül, E. (2013). Turkish return migration from Europe. European Review, 21(3), 412-421.

Düvell, F. (2019). The 'great migration' of summer 2015: Analyzing the assemblage of key drivers in Turkey. Journal of Ethnic and Migration Studies, 45(12), 2227-2240.

Düvell, F. (2020). Shifts in the global migration order and migration transitions in Europe: The cases of Turkey and Russia. Comparative Migration Studies, 8(1), 1-22.

ERC-European Research Council. (2017). Migration and asylum: The contribution of frontier research to the understanding of human mobility across frontiers. Luxemburg Publication Office of the European Union, 64 pp, Luxemburg.

Erdoğan, M. M. (2014). Türkiye'de Suriyeliler: Toplumsal kabul ve uyum araştırması. Hacettepe Üniversitesi, Göç ve Siyaset Araştırmaları Merkezi Raporu, HUGO.

Faist, T. (2003). Uluslararası göç ve ulus-aşırı toplumsal alanlar. İstanbul: Bağlam Yayınları.

Göç Raporu. (2016). T.C. İçişleri Bakanlığı. 2015 yıllık göç raporu. Nisan, 2016, Ankara: Göç İdaresi Genel Müdürlüğü Yayınları.

Göç Raporu. (2017). T.C. İçişleri Bakanlığı 2016 yllık göç raporu. Göç İdaresi Genel Müdürlüğü Yayınları Yayın No: 40 Nisan, 2017. 
Gökçen, S. (2015). Anadolu ve Balkanlar’a Romanların göçü. M. M. Erdoğan ve A. Kaya (Ed.), Türkiye'nin göç tarihi: 14. yüzyıldan 21. yüzyıla Türkiye'ye göçler (ss. 35-46), İstanbul: Bilgi Üniversitesi Yayınları.

Göker, G. (2015). Göç kimlik aidiyet: Kültürlerarası iletişim açısından İsveçli Türkler. Konya: Literatürk Academia Yayınları.

Güçlü, S. Ö. (2002). Kentlileşme ve göç sürecinde Antalya'da kent kültürü ve kentlilik bilinci. Ankara: Kültür Bakanlığı.

Güder, M. (2016). Türkiye'deki dış göç olgusuna sosyoekonomik bir yaklaşım ve Avrupa Birliği ile geri kabul anlaşması'nın olası etkileri. Sosyoekonomi, 24(4), 129-138.

Güleryüz, N. A. (2015). Geçmişten günümüze Anadolu'ya Yahudi göçü. Türkiyénin göç tarihi: 14. yüzyıldan 21. yüzyıla Türkiye’ye göçler (ss.47-73). İstanbul: İstanbul Bilgi Üniversitesi Yayınları.

Gürkan, M. (2006). Sosyolojik açıdan göç ve yasadışı göç hareketleri. (Yayınlanmamış Yüksek Lisans Tezi). Kırıkkale Üniversitesi, Sosyal Bilimler Enstitüsü, Sosyoloji Anabilim Dalı, Kırıkkale.

Ihlamur-Öner, S. G. (2012). Küresel bir göç ve mülteci rejimine doğru? T. Bora. (Ed.). Küreselleşme Çağında Göç: Kavramlar, Tartışmalar (pp. 577-600). İstanbul: İletişim Yayınları.

İçduygu, A. (2015). Türkiye’ye yönelen düzensiz göç dalgaları içinde "Transit Göç". Türkiye'nin göç tarihi: 14. yüzyıldan 21. yüzyıla Türkiye'ye göçler (pp. 277-294). İstanbul: İstanbul Bilgi Üniversitesi Yayınlarl.

İçduygu, A. \& Biehl, K. (2012). Kentler ve göç: Türkiye, İtalya, İspanya örnekleri. İstanbul: Bilgi Üniversitesi Yayınları.

Jauhiainen, J. S. (2020). Biogeopolitics of COVID-19: asylum-related migrants at the European Union Borderlands. Tijdschrift Voor Economische En Sociale Geografie, 111(3), 260-274.

Kale, B. (2015). Zorunlu göçün 19. yüzyılda Osmanlı İmparatorluğu üzerindeki etkileri. Türkiye'nin göç tarihi: 14. yüzyıldan 21. yüzyıla Türkiye’ye göçler (pp.133-151). İstanbul: İstanbul Bilgi Üniversitesi Yayınları.

Karpat, K. (2003). Türkiye ve Orta Asya. Ankara: İmge Yayınevi.

Kartal, B. T. \& Başçı, E. T. (2014). Türkiye'ye yönelik mülteci ve sığınmacı hareketleri. Celal Bayar Üniversitesi Sosyal Bilimler Enstitüsü Sosyal Bilimler Dergisi, 12(2), 275-299.

Kaya, A. (2015). Türkiye'de Çerkesler. Türkiye'nin göç tarihi: 14. yüzyıldan 21. yüzyıla Türkiye'ye göçler (pp.133-151). İstanbul: İstanbul Bilgi Üniversitesi Yayınları.

Kaya, G., \& Çolakoğlu, K. (2020). Geçici koruma kapsamındaki Suriyeli sığınmacıların Türkiye'deki onuncu yllına ilişkin sosyolojik bir analiz. Journal of International Social Research, 13(73), 594-609.

Kiziltepe, B. (2020). New trends in urban life of Turkey in the context of lifestyle migration. Open Journal for Sociological Studies, 4(2), 55-66.

Kolukırık, S. (2008). Türkiye'de Rom, Dom ve Lom gruplarının görünümü. Hacettepe Üniversitesi Türkiyat Araştırmaları (HÜTAD), (8), 145-154.

Kolukırık, S. (2009). Mülteci ve sığınmacı olgusunun medyadaki görünümü: Medya politiği üzerine bir değerlendirme. Gaziantep Üniversitesi Sosyal Bilimler Dergisi, 8(1), 1-20.

Kolukırık, S. (2014). Uluslararası göç ve Türkiye: Yerel uygulamalar ve görünümler. Zeitschrift für die Welt der Türken/Journal of World of Turks, 6(2), 37-53.

Kümbetoğlu, B. (2012). Göç çalışmalarında nasıl sorusu. T. Bora. (Ed.). Küreselleșme Çağına Göç: Kavramlar, Tartışmalar (pp. 49-85). İstanbul: İletişim Yayınları. 
Levent, T. (2019). A new challenge for urban planning in Turkey: Socio-spatial impacts of forced migration. European Spatial Research and Policy, 26(2), 115-134.

Mavroudi, E., \& Nagel, C. (2016). Global migration: Patterns, processes, and politics. Routledge.

Mukhra, R., Krishan, K., \& Kanchan, T. (2020). COVID-19 sets off mass migration in India. Archives of Medical Research, 51(7), 736-738.

Mülteciler Derneği, (2021). Türkiye'deki Suriyeli sayısı, Ocak 2021. Retrieved from https://multeciler.org.tr/turkiyedeki-suriyeli-sayisi/

Nizam, Ö. K., \& Gül, S. S. (2019). Türkiye'deki Suriyelilerin sosyolojik "yabancı" olarak ele alınması üzerine eleștirel bir değerlendirme. Süleyman Demirel Üniversitesi Fen-Edebiyat Fakültesi Sosyal Bilimler Dergisi, 2(47), 97-115.

Nurdoğan, A. K., \& Şahin, M. (2019). Türkiye'ye yönelen uluslararası göç işsizliğin bir nedeni mi? OPUS Uluslararası Toplum Araştırmaları Dergisi, 11(18), 2201-2223.

Ortaylı, İ. (2006). Genel göç olgusu. İstanbul organizasyon (Haz.). Uluslararası göç sempozyumubildiriler: 8-11 Aralık 2005 (s.19-22). İstanbul: Zeytinburnu Belediyesi.

Öner, N. A. Ş. (2012). Göç tartışmalarında temel kavramlar. T. Bora. (Ed.), Küreselleşme çağına göç: kavramlar, tartışmalar (pp.13-27). İstanbul: İletişim Yayınları.

Özbek, Y. (2010). Almanya'dan Türkiye'ye ulus-aşırı göç. B. Pusch ve T. Wilkoszweski (Ed.). Türkiye'ye uluslararası göç: toplumsal koşullar, bireysel yaşamlar (pp.159-170). İstanbul: Kitap Yayınevi.

Özdemir, H. (2012), 'Türkiye'de iç göçler üzerine genel bir değerlendirme', Akademik Bakış Dergisi, 30(11), 1-18.

Özerim, M. G. (2012). Turkey on the route of retirement migration: The motivations of European retirement migrants to prefer Turkey and their perception of Turkey. Journal of Yasar University, 28(7), 4766-4787.

Özgür, N. (2012). Modern Türkiye'nin zorunlu göçmenleri: Muhacirler, iskânlılar, mübadiller, islamlar, soydaşlar, "G" grubu, mülteciler, "tekne mülteciler. T. Bora. (Ed.). Küreselleşme çağına göç: kavramlar, tartışmalar (pp.199-216). İstanbul: İletişim Yayınları.

Özvarıș, Ș. B., Kayı, İ., Mardin, D., Sakarya, S., Ekzayez, A., Meagher, K., \& Patel, P. (2020). COVID-19 barriers and response strategies for refugees and undocumented migrants in Turkey. Journal of Migration and Health, 1(2), 1-8.

Parin, S. (2019). Toplumsal bellekte göç olgusu: Türkiye deneyimi. Journal of International Social Research, 12(65), 683-689.

Sirkeci, İ., Cohen, J. H. \& Yazgan, P. (2012). Türk göç kültürü: Türkiye ile Almanya arasında göç hareketleri, sosyo-ekonomik kalkınma ve çatışma. Migration Letters, 9(4), 373-386.

Suhardiman, D., Rigg, J., Bandur, M., Marschke, M., Miller, M. A., Pheuangsavanh, N., ... \& Taylor, D. (2021). On the coattails of globalization: migration, migrants and COVID-19 in Asia. Journal of Ethnic and Migration Studies, 47(1), 88-109.

Şaul, M. (2015). Geçmişten bugüne siyah Afrika'dan Türkiye'ye göçler: Kölelikten küresel girişimciliğe. Türkiye'nin göç tarihi: 14. yüzyıldan 21. yüzyıla Türkiye'ye göçler (pp.71-117). İstanbul: İstanbul Bilgi Üniversitesi Yayınları.

Şemşit, S., \& Çelik, D. Ş. (2019). Kale Avrupası yaklaşımı ve düzensiz göç. Paradoks Ekonomi Sosyoloji ve Politika Dergisi, 15(2), 279-294. 
Şen, M. T. (2014). Türkiye'de iç göçlerin neden ve sonuç kapsamında incelenmesi. Çalışma ve Toplum, (40), 231-256.

Tanrıkulu, F. (2020). The political economy of migration and integration: Effects of immigrants on the economy in Turkey. Journal of Immigrant \& Refugee Studies, 1-14.

Tekeli, İ. (2008). Göç ve ötesi (Vol. 3). Tarih Vakfi.

Transatlantik Eğilimler. (2013). Transatlantic trends key findings 2013, The german marshall fund of the United States strengthening transatlantic cooperation.

Tuzcu, P. (2008). Zorunlu göç ve küresel dönemde değişen nitelikleri: Türkiye üzerine bir inceleme. Yüksek Lisans Tezi, Kocaeli.

Türkiye Eğilimleri, (2019). Akademetre. İstanbul: Kadir Has Üniversitesi Yayınları.

UNHCR, (2019). Turkey fact sheet. Retrieved from https://www.unhcr.org/tr/wpcontent/uploads/sites/14/2019/11/UNHCR-Turkey -One-Pager-Fact-Sheet-Oct2019.pdf.

Ünal, Ç. (2019). Türkıye'nin I. düzey bölgelerinde göç istatistiklerinin değişim analizi (2007-2017). Trakya Üniversitesi Sosyal Bilimler Dergisi, 21(2), 737-758.

Ünal, S. (2014). Türkiye'nin beklenmedik konukları: "Öteki" bağlamında yabancı göçmen ve mülteci deneyimi. Journal of World of Turks / Zeitschrift Für Die Welt Der Türken, 6(3), 65-89.

Ünver, C. (2009). Uluslararası göç ve kalkınma tartışmalarında yeni yaklaşımlar ve Türkiye. TISK Academy / TISK Akademi, 4(7), 82-97.

Vollset, S. E., Goren, E., Yuan, C. W., Cao, J., Smith, A. E., Hsiao, T., ... \& Murray, C. J. (2020). Fertility, mortality, migration, and population scenarios for 195 countries and territories from 2017 to 2100 : A forecasting analysis for the global burden of disease study. The Lancet, 396(10258), 1285-1306.

Yakut, K. (2015). Geçmişten Kırım Tatarları ve Nogayların Osmanlı İmparatorluğu'na göçleri (17831922). Türkiye'nin göç tarihi: 14. yüzyıldan 21. yüzyıla Türkiye'ye göçler (pp.71-117), İstanbul: İstanbul Bilgi Üniversitesi Yayınları.

Yalçın, C. (2004). Göç sosyolojisi. Ankara: Anı Yayıncılık.

Yükseker, D \& Brewer, K. T. (2010). İstanbul'daki Afrikalı göçmen ve sığınmacıların yaşam koşulları. B. Pusch ve T. Wilkoszweski (Ed.). Türkiye'ye uluslararası göç: Toplumsal koşullar, bireysel yaşamlar (pp.297-319). İstanbul: Kitap Yayınevi.

Zorlu, M. \& Yetim, M. (2020). Yasa dışı göçle mücadele bağlamında Avrupa Birliği ve Türkiye politikalarının karşılaştırması. Ortadoğu Etütleri, 12(2), 1-23. 